\title{
SURFACE LAYER SALINITY OF YOUNG SEA ICE
}

\author{
by
}

\author{
Nobuo ONo AND TAKashi KaSAI
}

Institute of Low Temperature Science, Hokkaido University, Sapporo, Japan 060

\begin{abstract}
The high-salinity surface layer of young sea ice was subjected to field and laboratory experiments. Artificial pools, in which young ice was formed, were opened within a fast-ice sheet in the Saroma lagoon, Hokkaido, in February of 1983 and 1984. The salinity of $1 \mathrm{~mm}$ thick surface layer of the young ice was observed as high as $42.4 \%$, which exceeds the seawater salinity of $31 \%$. The surface salinity increased with rising surface temperature. When a load was placed on the fast ice near the pool, seeped brine of salinity $72.5 \%$ was observed on the surface of the young ice; and when the load was removed, the brine disappeared. Meanwhile, brine permeabilities, both upward and downward, were measured in the laboratory. Both permeabilities decreased logarithmically with lowering surface temperature. A remarkable anisotropy was observed: the upward permeability was greater than downward, and the ratio of upward to downward premeability increased with lowering surface temperature from 5 at $-3^{\circ} \mathrm{C}$ to 33 at $-5^{\circ} \mathrm{C}$. Upward and downward permeabilities in $\mathrm{ms}^{-1}$ were respectively $1 \times 10^{-4}$ and $2 \times 10^{-5}$ at $-3^{\circ} \mathrm{C}, 2 \times 10^{-5}$ and $6 \times 10^{-7}$ at $-5^{\circ} \mathrm{C}$, and at $-10^{\circ} \mathrm{C}$ upward permeability was $3 \times 10^{-7}$.
\end{abstract}

\section{INTRODUCTION}

It is well known that high-salinity surface brine exists on young sea ice. Wetness of the sea-ice surface due to surface brine affects the heat, vapour and salt transfers, as well as the emissivity of sea ice, which is important in the remote sensing of ice characteristics. Salinity of a thin surface layer of sea ice observed by Martin (1979) was as high as $50 \%$, which exceeds the salinity of seawater. This enhanced salinity is explained possibly by the upward migration of brine through the ice layer in defiance of gravity and temperature gradient. The causes of upward migration are considered to be brine expulsion due to an increment in volume as a result of ice formation on the wall of brine pockets with falling temperature, absorption of brine by snow cover due to capillary action, and seepage through brine channels because of relative depression of ice cover to the water level due to a load of snow or a vertical oscillation of ice cover.

To examine these possibilities, the high-salinity surface layer and the brine permeability of young ice were investigated in the field and laboratory.

\section{FIELD OBSERVATIONS}

Field experiments were carried out in February 1983 and 1984 at Saroma lagoon, Hokkaido. An artificial pool of $2 \mathrm{~m}$ square was made in a fast-ice sheet covering the lagoon. New crust ice several centimeters thick formed in the pool; the surface layer, $1 \mathrm{~mm}$ thick, was sampled to measure surface salinity. It was $42.4 \%$, exceeding the salinity of the underlying seawater $(31 \%)$, when the surface layer had no snow cover.

Variation in surface salinity with air temperature are shown in Figure 1. Surface salinity decreased gradually with falling air temperature, suggesting that brine expulsion does not contribute effectively to the formation of the high-salinity surface layer. Surface salinity increases with rising air temperature, to finally exceed the salinity of seawater.

Since the young ice in the pool was bound by fast ice, the brine within the young ice was forced out to the surface when the fast ice was depressed in relation to the

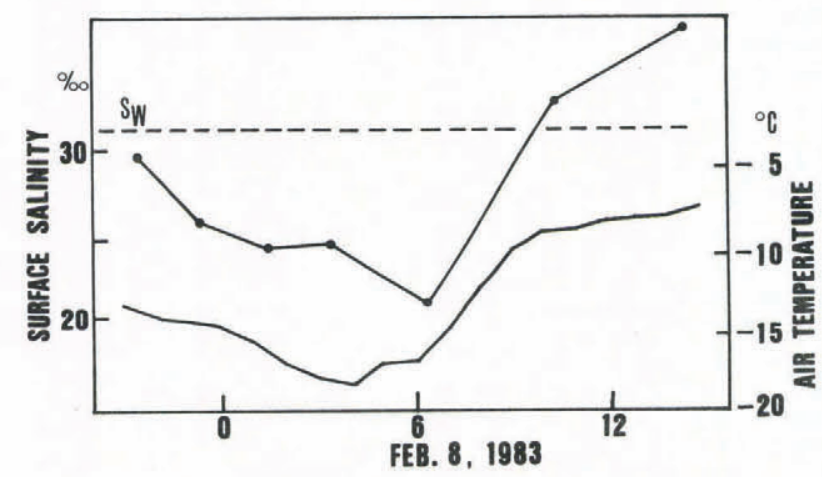

Fig.1. Variation in surface salinity of young ice with air temperature change. Solid circles: surface salinity; solid line: air temperature; dashed line: seawater salinity.

water level. To make an artificial depression, a loaded sled of about $75 \mathrm{~kg}$ was placed on the fast ice near the pool. Two types of surface ice were found in the pool; granular ice covered the leeward end and non-granular ice the windward end.

Seepage of brine was observed on the surface of the non-granular ice soon after the placement of sled, while on the surface of granular ice, brine seepage was observed several minutes later. The salinity of the seeped brine on the non-granular ice was observed as high as $72.5 \%$. When the load was removed, the seeped brine on the non-granular ice disappeared quickly, while that on the granular ice decreased gradually.

Salinities of the $1 \mathrm{~mm}$ thick surface layer of the two types of ice appear in Figure 2. Both the surface salinity and its changes were greater on the non-granular than on the granular ice.

\section{ANISOTROPY IN BRINE PERMEABILITY OF SEA ICE}

Both upward and downward brine permeabilities of sea ice were measured in the laboratory. Two $50 \mathrm{~cm}$ deep tanks $30 \mathrm{~cm}$ square and $20 \mathrm{~cm}$ square in cross section, connected by a flexible tube near the bottom, were placed in an insulated box in a cold room kept at $-20^{\circ} \mathrm{C}$. They

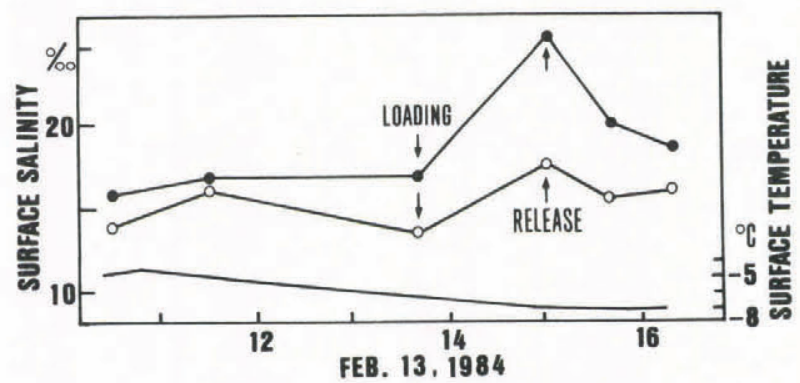

Fig.2. Changes in salinity of $1 \mathrm{~mm}$ thick surface layer of two kinds of ice before and after loading. Open circles: salinity of granular ice; solid circles: salinity of non-granular ice; solid line: surface temperature. 
were filled with seawater, and that in the small tank was kept unfrozen. When a crust of new ice grew $6 \mathrm{~cm}$ thick in the large tank, the surface temperature of the ice crust was raised to a desired temperature using an infrared lamp. The upward and the downward permeabilities of this ice were measured by adjusting the water level of the small tank as follows: for upward permeability measurement seawater was poured into the small tank to keep a constant water level above the ice surface, and for downward permeability measurement concentrated seawater, of salinity in equilibrium with the ice surface temperature, was added to the surface of the ice crust, and the water level in the small tank was lowered in relation to the ice surface. Both permeabilities were calculated from changes in head of water.

The dependence of upward and downward permeabilities on surface temperature is shown in Figure 3. Both decreased logarithmically with falling surface

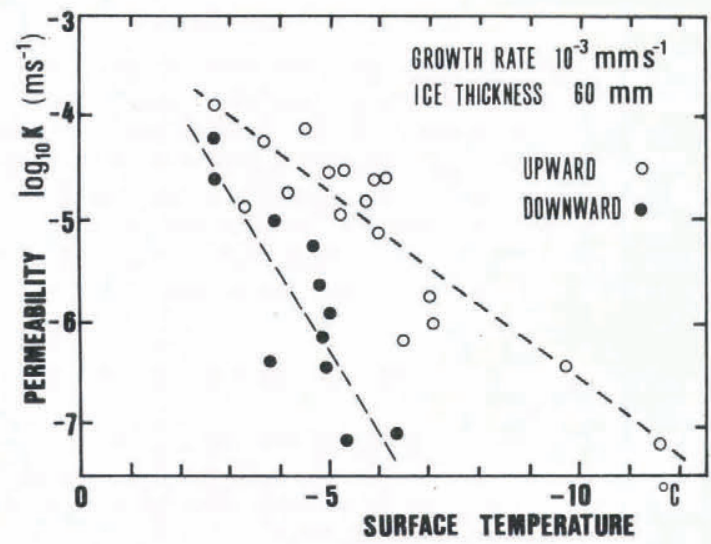

Fig.3. The dependence of brine permeability of sea ice on surface temperature. Open circles: upward permeability; solid circles: downward permeability.

temperature. Upward permeability is greater than downward permeability, and this anisotropy, the ratio of upward to downward permeability, increases with lowering surface temperature from 5 at $-3^{\circ} \mathrm{C}$ to 33 at $-5^{\circ} \mathrm{C}$. Upward and downward permeabilities $\left(\mathrm{ms}^{-1}\right)$ are, respectively, $1 \times 10^{-4}$ and $2 \times 10^{-5}$ at the surface temperature of $-3^{\circ} \mathrm{C}, 2 \times 10^{-5}$ and $6 \times 10^{-7}$ at $-5^{\circ} \mathrm{C}$, and the upward permeability is $3 \times 10^{-7}$ at $-10^{\circ} \mathrm{C}$.

\section{DISCUSSION}

Surface layer salinity of young ice of ten exceeds the salinity of seawater. It is caused by the upward migration of brine and its retention within the surface layer.

Our results suggest that, since upward mobility of brine is greater than downward, a progressive increase in surface salinity occurs under the ice when cover is depressed relatively to the water level. Moreover, since the downward permeability falls considerably more than the upward one with falling surface temperature, downward brine migration in the surface layer becomes inactive with ice growth.

On the other hand, Saito and Ono (1978) pointed out that surface granular ice is markedly less permeable than the lower part of sea ice, which consisted of columnar ice. Their results are confirmed by the present field observations that brine seepage on the granular ice was very slow.

We conclude that the high-salinity surface layer is formed on young sea ice as a consequence of upward brine migration and the continuing stay of the brine within the surface layer. Factors causing the upward brine migration are seepage of brine through the brine channels when ice cover is depressed relatively to the water level, and the absorption of brine by the snow cover. Factors that keep the brine within the surface layer are both the anisotropy and the temperature dependence of permeability of sea ice, which are characterized by the structure of the surface granular ice and the configuration of brine channels.

The effect of evaporation from surface brine and/or ice is considered small from our preliminary experiments; however, this needs further investigation.

\section{ACKNOWLEDGEMENT}

This work was partly supported by the Grant-in-Aid for Scientific Research (56460037) from the Ministry of Education, Science and Culture of Japan.

\section{REFERENCES}

Martin S 1979 A field study of brine drainage and oil entrainment in first-year sea ice. Journal of Glaciology 22(88): 473-502

Saito T, Ono N 1978 [Percolation of sea ice. I. Measurements of kerosene permeability of $\mathrm{NaCl}$ ice.] Low Temperature Science A37: 55-62 (In Japanese with 